\title{
Methods of acute biological assays in guinea-pigs for the study of toxicity and innocuity of drugs and chemicals
}

\author{
Gui Mi Ko ${ }^{1, *}$, Adela Rosenkranz ${ }^{1,2}$, Clélia Rejane Antonio Bertoncini ${ }^{1}$, Neide Hyppolito Jurkiewicz ${ }^{2}$, \\ Mirian Ghiraldini Franco ${ }^{1}$, Aron Jurkiewicz ${ }^{1,2}$
}

\author{
${ }^{1}$ Center for Development of Models for Medicine and Experimental Biology (Cedeme), Federal University of São Paulo, \\ ${ }^{2}$ Department of Pharmacology, Federal University of São Paulo
}

\begin{abstract}
In this study, 602 samples were tested by the following assays performed at the animal facilities (Cedeme) of the Federal University of São Paulo (UNIFESP): 385 for dermal irritability, 90 for ocular irritability (discontinued in 1995), 31 for systemic toxicity by injection, 26 for oral acute toxicity, 15 for toxicity by intracutaneous injection, 15 for skin sensitization, 15 for toxicity of serum and vaccines for human use, 14 for toxicity by intramuscular implantation, 7 for pyrogens, 2 for acute dermal toxicity, and 2 for irritation of mucous membrane. The following agents were tested: cosmetics and related substances $(42.0 \%)$, chemicals used in industry $(32.9 \%)$, plastics, rubber, and other polymers $(15.9 \%)$, agrotoxics $(4.0 \%)$, medicines $(2.7 \%)$, and vaccines $(2.5 \%)$. In the present description, emphasis was given to tests of dermal irritability and sensitization. This work was conducted entirely in animal facilities, according to our general belief that animal facilities at universities, while considering ethic principles and sanitary, genetic, nutritional, and pathophysiological controls, also require laboratories specialized in areas such as transgenics, cryopreservation, ambiental physiology, functional genomics, alternative models, and mainly activities and research on methods in toxicology, as focused in this study.
\end{abstract}

Uniterms: Acute biological assays/methods. Cosmetics/toxicity/experimental study. Cosmetics/innocuity. Drugs/toxicity/experimental study. Drugs/innocuity. Chemical substances/toxicity/experimental study. Dermal irritability/experimental study.

Descrevemos os testes usados em ensaios biológicos de curta duração para estudo de toxicidade e inocuidade de cosméticos, fármacos e outras substâncias químicas, feitos no Biotério Central/Cedeme da Unifesp, de 1986 a 2000. Testamos 602 amostras nos seguintes ensaios: 385 de irritação cutânea, 90 de irritação ocular (até 1995), 31 de toxicidade sistêmica por injeção, 26 de toxicidade oral aguda, 15 de toxicidade por aplicação intracutânea, 15 de sensibilização da pele, 15 de toxicidade de soros e vacinas de uso humano, 14 de toxicidade por implantação intramuscular, 7 de pirogênio, 2 de toxicidade dérmica aguda e 2 de irritação da mucosa. Os agentes testados foram: cosméticos e suas matérias-primas (42,0\%), substâncias químicas industriais (32,9\%), plásticos, borrachas e outros polímeros $(15,9 \%)$, defensivos agrícolas $(4,0 \%)$, medicamentos $(2,7 \%)$ e vacinas $(2,5 \%)$. Aqui daremos ênfase aos ensaios de irritação e sensibilização cutânea. Este trabalho foi feito inteiramente em biotério, em consonância com a idéia de que os biotérios em universidades, sem deixar de considerar os princípios éticos pertinentes e sem desconsiderar a presença de laboratórios para controles sanitário, genético, nutricional e fisiopatológico, devem ter também laboratórios para pesquisa em transgênicos, criopreservação, fisiologia ambiental, genômica funcional, modelos alternativos e fundamentalmente toxicologia, entre outros.

Unitermos: Ensaios biológicos agudos/métodos. Cosméticos/toxicidade/estudo experimental. Cosméticos/inocuidade. Drogas/inocuidade. Drogas/toxicidade/estudo experimental. Agentes químicos/ toxicidade/estudo experimental. Irritabilidade cutânea/estudo experimental.

*Correspondence: Gui Mi Ko. Cedeme - UNIFESP. Rua Botucatu, 862 - Vila

Clementino - 0423062 - São Paulo - SP, Brasil. Email: guimiko.cedeme@epm.br 


\section{INTRODUCTION}

Toxicity can be defined as a change in cell homeostasis by modifying the ability of the cell for adaptation, survival, reproduction or to perform specific functions (Middleton, 1981), whereas innocuity is defined as the absence of toxicity.

Traditionally, the study of drugs and chemicals for toxicity determination has included acute, sub chronic and chronic studies, as well as reproduction in young or adult animals. In addition, in recent decades the range of toxicological studies has broadened by including potentially adverse effects at all stages of reproduction and development, as well as genetic alterations, tumor induction, immunological effects, and irritation of tissues (Morton, 1981).

One of the main objectives of toxicological tests is to obtain a prognostic for the effects of substances on human beings, based on the effects observed in animals or in other biological systems. The tests of toxicity are performed to assure the safety for the use of medicines, food or other products destined for public consumption, or to determine the extent of occupational hazards of industrial substances, through the identification of effects that are unknown or suspected (Swanston, 1985). These effects can vary according to the species and depend on biodisponibility and reactivity of the agent on its receptor sites in different tissues, among other factors. Comparative studies if available, together with toxicological pilot data for various species, can furnish a solid base for protocols of appropriate toxicological assays (Morton, 1998).

Short duration assays on animals to evaluate toxicity and safety in humans were first introduced at the Central animal facility of Escola Paulista de Medicina (today Cedeme of EPM/Unifesp) in 1984 by Adela Rosenkranz and Aron Jurkiewicz. These tests have been adapted since 1986, mainly to meet the needs of laboratories dealing with cosmetics, chemicals, or pharmaceuticals. Over a period of about 15 years, 602 tests have been carried out, divided into 11 types of assays (Figure 1) and in which 6 different types of agents were evaluated (Figure 2). The performance of these tests was in line with the objectives pursued during this period, which was for an Animal Facility to be not only a producer of animals, but also an effective participant and component of the triple objective of the University, represented by Extension, Teaching and Research.

\section{Strategies for the performance of toxicity tests}

Toxicity tests can be divided into general and specific groups, according to Loomis (1975). The first group consists of tests performed to evaluate the general toxic effects of
Types of tests conducted at CEDEME 1986-2000

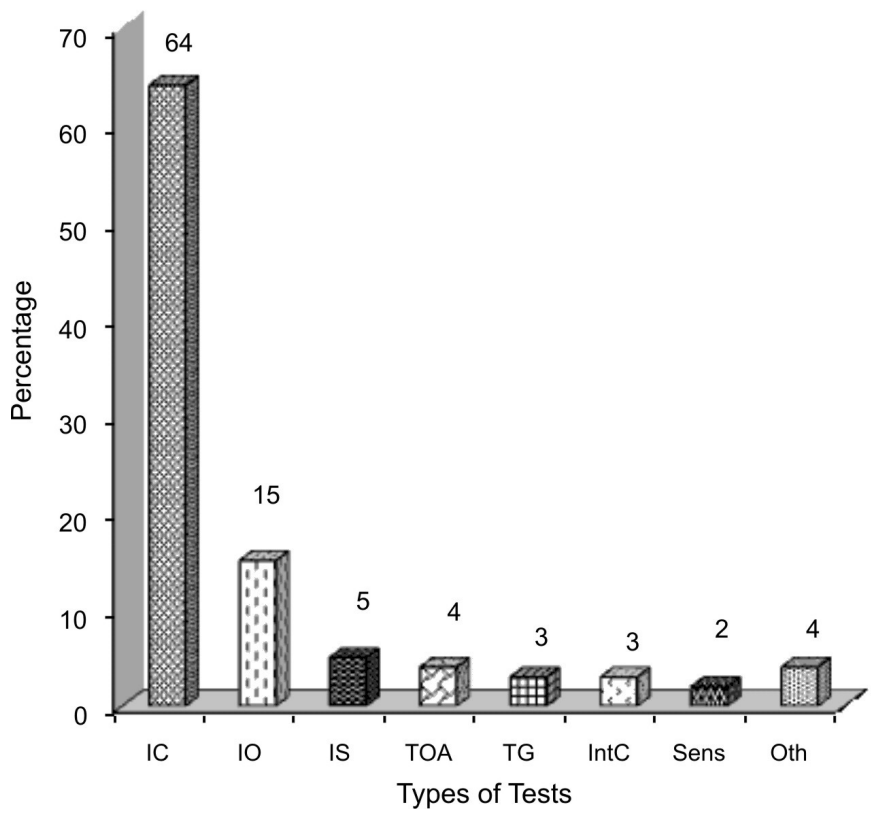

FIGURE 1 - Acute biological assays, considering percentages for 602 tests conducted at Cedeme/Unifesp between 1986 and 2000. The types of assay are indicated in abscissa: $\mathrm{IC}=$ cutaneous irritation; $\mathrm{IO}=$ eye irritation (not after 1995); IS= Systemic Injection; $\mathrm{TOA}=$ Oral acute toxicity; $\mathrm{TG}=$ General toxicity; $\mathrm{IntC}=$ Intracutaneous toxicity; Sens= Sensitization of skin; Oth $=$ other (Implantation, Pyrogen, Acute dermal toxicity, and Mucosa Irritation).

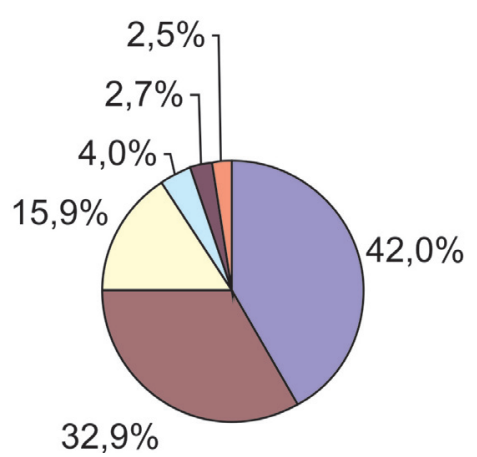

$\square$ cosmetics and related substances

$\square$ industrial chemical agents

$\square$ plastics, rubber and other polymers $\square$ agrotoxics

medicines

vaccines

FIGURE 2 - Types of agents and respective percentage of samples submitted to acute biological assays in 602 tests conducted at Cedeme/Unifesp, from 1986 to 2000, as indicated in the previous figure.

a number of compounds. In this group, the types of tests are considered basically in relation to duration, number of expositions, the agent, and summation of the organs and systems involved in the evaluation. The duration of a given test can be acute, sub chronic or chronic. The second group consists of tests for the determination of specific types of toxicity (cutaneous, immunological, teratogenic, mutagenic, 
carcinogenic, reproduction, pharmacologic synergism or antagonism, neurotoxicity etc), including that for defined organs or systems which may or may not be taken into account in the first general test group.

Acute toxicity has been taken to define the adverse effects induced during a short period of administration of a single dose or of multiple doses within a period of 24 hours (Hangan, 1959). However, its meaning is sometimes considered as acceptable for any multiple expositions during a short period of time that is not explicitly defined. However, the limit of 24 hours is in general admissible. Occasionally, the term acute is used to express the duration of response, rather than the time of exposition (Brown, 1981).

In 1944, Draize and collaborators published a classic paper produced at their laboratory at the Division of Pharmacology of the Food and Drug Administration (FDA) in Washington, about local and systemic toxicity in skin and mucosa. This group tested a large number of organic compounds and some inorganic agents. These studies led to the development of new methods, complementation of some previously described methods, and development of new procedures for evaluation of toxicity. In the study, detailed descriptions of techniques and procedures were presented for the following tests in animals: acute cutaneous toxicity, sub acute cutaneous toxicity ( 21 and 90 days), primary irritation of the skin and mucosa, primary irritation of the eye and sensitization. In addition, a test was described for skin irritation in men (Draize et al., 1944).

Some two decades later, Somers (1964) described methods for determination of local skin and mucosa toxicity, and methods to evaluate systemic toxicity due to acute and chronic exposure of the skin. A test for primary cutaneous irritation of the skin of animals, using a method similar to that described by Draize $(1944,1959)$ was also described for rabbits or guinea-pigs.

\section{Cutaneous toxicity}

The cutaneous toxicity of various substances can be divided into (a) primary irritation (irritation dermatitis), or (b) problems caused by sensitization of the skin (allergic dermatitis). A reaction of skin sensitization represents an allergic reaction to chemical agents and depends on previous exposure for its development. Allergic reactions are relatively common in humans, but cannot be easily reproduced in animals (Somers, 1964). In the working population, the incidence of these two reactions varies with the type of industry and the gender of the worker, but both are equally important. The term primary irritation is usually associated with the test procedure that evaluates the inflammatory response. Thus, an irritant is frequen- tly defined as a chemical that induces an inflammatory response. However, this definition omits other cellular characteristics, as mentioned by Middleton (1981), such as the ability for adaptation, survival, and reproduction.

The present article is an overview of some of the tests performed in Cedeme between 1986 and 2000, concerning primary cutaneous irritation and sensitization using mainly cosmetics, various chemicals, medicines and vaccines. Since the assays were performed using exogamic guinea-pigs, it seems fitting to justify the use of this animal for our tests.

\section{The guinea-pig as a model of choice for the study of cutaneous toxicity}

The guinea-pig is a good model for toxicity tests for the following main reasons:

1. Primary skin irritations are usually screened using guinea pigs (Klecak et al., 1977) although rabbits have also been used for this purpose. It has been suggested that the guinea-pig should be the animal of choice, because its skin is more similar to human skin (Somers, 1964). Furthermore, in the guineapig it is possible to extend the study to incorporate an analysis of contact sensitization. Tests for a prognostic of the potentiality for induction of late hypersensitivity in humans have been run in guineapigs (Parish, 1981). These sensitizations are due mainly to histamine, which is released by mastocytes through a secretion process during inflammation or allergy. Sensitization involving the effects of histamine or other endogenous agents varies according to the type of tissue and animal species. For instance, the guinea-pig is very sensitive, whereas the mouse is less sensitive to this agent (Silva, 1997).

2. The analysis of various publications (Brown, 1971; Davies et al., 1972; Marzulli, Maibach, 1975) indicates that although the rabbit is also very sensitive, the results in guinea-pigs show a better similarity and correlation with findings in human beings.

3. The guinea-pig is docile and easy to handle. It is easy to depilate compared to other animal species.

4. The guinea-pig is smaller than the rabbit, thus occupying less space in the animal facility.

5. There are genetic hairless guinea-pig models. The use of hairless guinea-pigs assures that the penetration of the substance being tested occurs via the corneal sheet of the skin and not through skin annexes, in hair follicles for instance. Hairless guinea-pigs can be easily purchased, for instance at Charles River Laboratory, USA. 


\section{ASSAYS PERFORMED}

Of the 602 tests performed during the 1996 to 2000 period, 385 were for primary cutaneous irritation and 15 for sensitization, with a total of 400 assays. Figure II shows that the agents tested were predominantly cosmetics, followed by industrial chemicals and finally by plastics, rubber and other polymers, agrotoxics, and medicines. The tests of sensitization were conducted for plastics and industrial chemicals including disposable feminine sanitary pads and tampons, $12(80 \%)$ employing the method of OECD (Organization for Economic Cooperation and Development) and 3 (20\%) using the method of OET (Open Epicutaneous Test). The remaining 202 assays will be presented and described briefly at the end (Table IX), after the presentation of irritation and sensitization tests.

\section{TESTS OF CUTANEOUS IRRITATION AND SENSITIZATION}

The tests for (a) cutaneous irritation and (b) skin sensitization, by means of two methods, namely OECD and OET, will be described separately. In each case, a description will be made for the main items involved in the methodologies that will be illustrated using examples of results obtained in our laboratory.

\section{MATERIAL AND METHODS}

\section{Animals}

Exogamic male and female albino adult DunkinHartley guinea-pigs weighing 450-600 g were used. Animals were maintained in centrally filtered air at controlled temperature $\left(22 \pm 2{ }^{\circ} \mathrm{C}\right)$ and humidity $(55 \pm 10 \%)$, with 15 air renovations per hour, and photoperiodicity of 12/12 h. Animals were fed daily with commercial feed, fresh vegetables, and water ad libitum.

\section{Chemical compounds}

The compounds used in the six hundred and two tests were produced by various industries with different uses, as shown in Figure II. Most of them were delivered to us with a code number, and their chemical nature was usually not given. Their possible toxicity or allergenicity was usually unknown to the persons performing the tests, unless informed a priori by the industry or laboratory involved.

\section{Test for cutaneous irritation}

The method used was that described by Lautier et al. (1978). In addition, the descriptions given in the Guidelines for testing chemicals No.404 of OECD (1981a), of the test for cutaneous irritation (Draize, 1944), and of the USA Code of Federal Regulations (USA CFR, 1976) were followed.

\section{Preparation of animals and agents tested}

The skin of the guinea-pigs was clipped 24 hours before the application of the substance being tested: the skin of the mid back of the animal behind the shoulders (area to be treated) and a second area, about $3 \mathrm{~cm}$ underneath (area for control), were clipped with an electrical Oster clipper. Only animals with intact undamaged skin were used.

The substances to be tested which came in solid form were humidified with sterilized physiological solution (or pulverized, if necessary), to assure the maintenance of good contact with the skin. Strongly acid or strongly alkaline substances with $\mathrm{pHs}$ less than or equal to 2.0 , or greater than or equal to 11.5 , were not used for primary dermal irritation.

\section{Procedure for using the samples to be tested}

The substance being tested $(0.5 \mathrm{~mL}$ or $0.5 \mathrm{~g})$ was placed on a $2 \times 2 \mathrm{~cm}$ squared sterile gauze and placed over the intact skin in the center of the back of the 1st to the 6 th guinea-pigs. For the 7 th to the 12 th guinea pigs, the skin underwent abrasions with a sterilized hypodermic 20 gauge needle, by making 3 parallel superficial incisions, $0.5 \mathrm{~cm}$ apart, avoiding bleeding. The gauze was covered with a small sterilized cotton pad, under two additional strips of gauze forming an $\mathrm{X}$, followed by another pad of sterile gauze, to increase the overall thickness, where this was finally surrounded by a hypoallergenic surgical adhesive tape around the thorax (and abdomen if necessary) of the animal.

\section{Procedure for reading the results}

After 18 hours of exposition the gauze bandage was removed, and the 1 st reading taken after another 6 hours ( 24 hours after the beginning of application). The two additional readings were taken at 24-hour intervals.

Besides the measurement of erythema and edema (using a slide caliper), other toxic effects were taken into account when evident. This was followed by a classification of the degree of the dermal reaction which was scored between 0 and 4, according to the corresponding reaction (Tables I and II). 
TABLE I - Number and percentage of assays for cutaneous irritation in guinea-pigs, according to the degree of irritation and type of agent assayed ${ }^{\text {a }}$

\begin{tabular}{|c|c|c|c|c|c|c|}
\hline Degree of irritation & $\begin{array}{l}\text { Cosmetics and } \\
\text { related substances }\end{array}$ & Medicines & $\begin{array}{c}\text { Plastics, rubber } \\
\text { and other } \\
\text { polymers }\end{array}$ & $\begin{array}{l}\text { Industrial } \\
\text { chemicals }\end{array}$ & Agrotoxics & Total \\
\hline Not irritating & 128 & 03 & 10 & 47 & 06 & 194 \\
\hline Slightly irritating & 46 & 01 & 0 & 74 & 04 & 125 \\
\hline Moderately irritating & 15 & 0 & 0 & 51 & 0 & 66 \\
\hline Severely irritating & 0 & 0 & 0 & 0 & 0 & 0 \\
\hline Total & 189 & 04 & 10 & 172 & 10 & 385 \\
\hline Percentage & 49.01 & 1.04 & 2.60 & 44.68 & 2.60 & 100 \\
\hline
\end{tabular}

${ }^{\mathrm{a}}$ Conducted at Cedeme between 1986 and 2000.

TABLE II - Evaluation of guinea-pig skin reactions in cutaneous irritation tests

\begin{tabular}{lll}
\hline Skin reactions & Degree of reaction & Score \\
\hline Erythema and eschar formation & No erythema & 0 \\
& Very slight erythema (barely perceptible) & 1 \\
& Well-defined erythema & 2 \\
& Moderate to severe erythema & 3 \\
Edema Formation & Severe erythema (beet redness) to slight eschar formation (deep injuries) \\
& No edema & \\
& Very slight edema (barely perceptible) & \\
& Slight edema (edges of area well delineated by definite swelling) \\
& Moderate edema (raised approximately 1 mm) \\
& Severe edema (raised more than 1 mm and extending beyond area of exposure) & 4 \\
\hline
\end{tabular}

\section{Irritation index based on reading}

A primary irritation index (IIP) was calculated as the arithmetic mean of the 24 and 72-hour readings of erythema and edema, followed by the classification of the samples as not irritating $(0-0.9)$, slightly irritating (1 1.9), moderately irritating $(2-4.9)$ and severely irritating $(5-8)$, according to the respective IIP value in parenthesis.

\section{Tests of skin sensitization}

Two methods were used to test skin sensitization: the method described in Guideline No 406 of the OECD (1981b), and the OET method (Klecak et al., 1977).

\section{Skin sensitization test by the OECD method}

\section{Main general procedure}

This method consists of an initial phase of induction followed by a procedure of challenge. The method relies on the dissolution of the samples in a diluent containing a preparation of guinea-pig fat, as described below. In addition, the use of a depilatory cream is also recommended to facilitate the handling of the skin.

\section{- Preparation of guinea-pig fat}

The steps followed for the preparation and storage of the fat are described in Guideline $\mathrm{N}^{\circ} 406$ of the OECD (1981b).

\section{- Preparation of depilatory cream}

The use of the following depilatory cream is not obligatory, but is ideal because of easy handling and good results: 6 parts soluble starch, 6 parts talc, 6 parts barium sulphide, 2.7 parts of a granular non-irritant anionic surfactant.

The parts are added in the order listed and mixed well. Cold water is added to make a viscous paste. The depilatory is applied to the clipped skin of the guinea pig (made with sharp scissors) and allowed to remain for around four minutes. Traces of depilatory are rinsed immediately afterwards.

\section{Procedure for experimental induction}

A mixture of $1.0 \%$ (weight/volume) of the sample was prepared in Freund 's Complete Adjuvant (FCA) and gently stirred at room temperature for 3 hours. After some minutes for stabilization, $0.05 \mathrm{~mL}$ of the mixture 
was injected into the anterior paw from the $1^{\text {st }}$ to the $10^{\text {th }}$ guinea-pig, while the $11^{\text {th }}$ to $20^{\text {th }}$ control guinea-pigs were injected with only FCA. The animals were never exposed to the samples before the test.

\section{Procedure for experimental challenge}

After one week the sample was mixed at the concentration of $1 \%$ in a solvent composed of guinea-pig fat, dioxane and acetone at the proportion of 1:2:7. A lower concentration, of $0.1 \%$, was used when the $1 \%$ solution had previously induced a moderate or higher irritation. Each animal previously submitted to induction was now tested for the challenge procedure, by applying a drop of $0.3 \mathrm{~mL}$ to the skin of the inferior back, closely clipped with sharp scissors. The guinea-pigs of the control group were similarly challenged. Approximately 24 hours after exposition, the area of application was peeled with an Oster electrical clipper (or depilatory cream as described above), followed by washing with tap water, in order to allow the reading of edema and erythema 3 hours after depilation under a uniform fluorescent light.

\section{Strategy for reading the results}

Approximately 24 hours after the challenge procedure, the animals were peeled again, and 3 hours after depilation the site of application was observed under uniform fluorescent light to check for the degree of irritation. This was determined based on criteria similar to those presented in Table II, taking the non-treated skin as control. A second reading was made 48 hours after application.

\section{Skin sensitization test by the OET method (Open Epicutaneous Test)}

\section{Method}

The OET method was used based on the description of Klecak et al. (1977). The methodological differences in relation to the OECD procedure refer to different procedures of induction and challenge, listed in Table III and detailed for each of the methods under the topics related to the respective experimental procedures.

\section{Experimental Procedure - Test of cutaneous irritation, as a pre-requisite}

Preceding the induction procedure, it is necessary to ascertain the absence of skin irritation that, if present, could interfere with the method of sensitization. To attain this objective the lowest concentration that would cause erythema in a minimum of $25 \%$ of the animals was determined. The maximum nonirritating concentration was also determined, considered to be the maximal sample concentration that does not cause macroscopically perceptible irritation in the animal. The confirmation of an absence of irritation is an essential condition to start the procedure for the method of sensitization.

As an example, samples of two shellac paints, A and $\mathrm{B}$, were used for this preliminary irritation test. Initially, a drop of $0.025 \mathrm{~mL}$ of each of the two nondiluted samples were placed by means of a pipette directly onto the skin within an area of $2 \mathrm{~cm}^{2}$ marked as a circle on the back that had been peeled 24 hours earlier. In additional, groups of 6 animals each with sample solutions diluted by $30 \%$, $10 \%$ or $3 \%$ were tested similarly as done for the initial nondiluted solution. The reading was made 24 hours after application, in order to construct a dose-response curve.

\section{Dose-response curve for cutaneous irritation - as part} of pre-requisite

A dose-response curve was constructed using nondiluted concentrations, as well as diluted solutions of $30 \%, 10 \%$ and $3 \%$ (more diluted concentrations, of $1.0 \%$, $0.3 \%, 0.1 \%$ and $0.03 \%$, could have been used but were not necessary) in acetone (although other solvents could have been used), for determination of a minimal irritating concentration and the maximal non-irritating concentrations.

The use of higher concentrations of samples in the tests was based on their solubility and on their capability of not causing cutaneous irritation, i.e., concentrations that

TABLE III - Differences between parameters used for sensitization tests according to the guidelines of OECD and OET

\begin{tabular}{llll}
\hline Test phase & Parameters & OECD & OET \\
\hline Induction & Number of groups (concentrations used) & One & At least four \\
& Animals per group & 10 & 6 or more \\
& Use of Freund's Complete Adjuvant & Yes & No \\
& Route of administration & Injection in paw & Topic on skin \\
& Duration & Single dose & 21 daily doses \\
Challenge & Place of challenge & Topic on skin & Topic on skin \\
& Number of challenges & 1 & 2 \\
& Time for a challenge after the end of induction & 7 days & 1 and 14 days \\
\hline
\end{tabular}


would not cause strong reactions, such as edema, necrosis or ulceration.

\section{Check for absence of irritation - as final part of pre- requisite}

For the confirmation or otherwise of an absence of skin irritation, readings were taken of edema and erythema 24 hours after the application of the groups of dilutions mentioned above. A score of zero was detected for edema and erythema for the group with $3 \%$ dilution (the slightly red color was removed by the solvent). Thus, we could assert that the concentration of $3 \%$ did not cause any irritation to the skin, thus justifying the beginning of the induction test by the OET method, followed by the challenge test.

\section{Procedure for experimental Induction}

On day zero, $0.1 \mathrm{~mL}$ of the nondiluted sample and other respective dilutions $(30 \%, 10 \%$ and $3 \%$, for each group) were applied to an area of peeled skin of about $8 \mathrm{~cm}^{2}$ at the thoracic dorsum of 6 guinea-pigs per group, using 4 groups (a different dose for each group) for each sample. This was similarly described above for the prerequisite for cutaneous irritation. However, contrary to the pre-requisite, in which the application was made for only one day, the induction applications were repeated daily for 21 days, always using the same place for application at the same site to the right hand side of the back. The reactions were read 24 hours after each application. The maximal non-irritating and the minimal irritating concentrations were determined.

\section{Procedure for experimental challenge - Check for sensitization}

In order to determine if allergic contact dermatitis had been detected, the guinea-pigs that were previously induced for 21 days, as well as the 6 non-treated control guinea-pigs, were challenged at day 21 (last day of induction) and day 35, by applying $0.025 \mathrm{~mL}$ of a sample presenting a minimal concentration for irritation, and nonirritating concentrations, on the left peeled back in $2 \mathrm{~cm}^{2}$ marked areas. Readings were made 24, 48 and 72 hours after application, based on criteria similar to those presented in Table II. Therefore, the minimal concentration necessary to induce contact hypersensivity was determined.

\section{Criteria for interpretation of results}

A sample is considered as allergenic if at least 2 of the 6 animals of a group present a reading of edema and erythema, by applying a concentration known to be non-irritating. For the sake of confirmation, microscopic examinations were also made for the skin samples defined as having a positive reaction for sensitization.

\section{RESULTS AND DISCUSSION}

\section{Test of cutaneous irritation}

\section{Results}

Based on the readings and indexes of irritation, the results were classified according to the criteria stated in the method of Lautier et al. (1978). Four groups were considered from the results obtained in all 385 tests: based on the degree of irritation, $50.39 \%$ of the agents tested were classified as non-irritating, $32.47 \%$ as slightly irritating, $17.14 \%$ as moderately irritating, and $0 \%$ as severely irritating (Table I).

As an example, Table IV shows the results of the trials run for 3 cosmetics, tested in May 1989, using 6 guinea-pigs per sample. The indexes of primary irritation varied from 1.5 (slightly irritating) for cosmetic A, to 2.3 (cosmetic B) and 3.0 (cosmetic C). Thus, the agents B and $\mathrm{C}$ were classified as moderate irritants.

The results of another study are shown in Table V. This test was conducted in July 1989 for a chemical agent used in automobile industry, in which 12 guineapigs were used $\left(1^{\text {st }}\right.$ to $6^{\text {th }}$ guinea-pigs with normal skin, and $7^{\text {th }}$ to $12^{\text {th }}$ guinea-pigs with abraded skin). The sample tested presented an index of primary irritation of 2.8 , corresponding to the classification of moderate irritating.

Finally, Table VI shows the results of the study carried out for a liquid soap in November 1993, using 12 guinea-pigs. The sample tested, with washouts performed 5 minutes after application, presented an index of primary irritation of 0.0 , corresponding to the classification of non-irritating.

\section{Test for skin sensitization by the OECD method}

\section{Results}

Fifteen tests of sensitization were performed since 1990, of which 12 were performed by the method of OECD and 3 by the method of OET, as described above, where samples were classified in the end as non-sensitizing $(80 \%)$ or sensitizing $(20 \%)$.

As an example, Table VII shows the results of a test to measure contact sensitization of two samples of shellac paints A and B, by the OECD method run in February 1992. Twenty guinea-pigs were used $\left(1^{\text {st }}\right.$ to $10^{\text {th }}$ guinea-pigs in test group and $11^{\text {th }}$ to $20^{\text {th }}$ guinea-pigs in control group). The difference between the means of edema and erythema for 
TABLE IV - Edema (Ed), Erythema (Er) and Primary irritation index (IIP $)^{a}$ measured from tests conducted after application of 3 samples (A, B, C) of cosmetics, using 6 guinea-pigs (1 to 6) for each group of samples, performed in May 1989

\begin{tabular}{|c|c|c|c|c|c|c|c|c|}
\hline \multirow[t]{3}{*}{ Sample } & \multirow{3}{*}{$\begin{array}{c}\text { Time of } \\
\text { Application } \\
\text { (h) }\end{array}$} & \multicolumn{7}{|c|}{ Guinea-pig } \\
\hline & & 1 & 2 & 3 & 4 & 5 & 6 & Sum \\
\hline & & $\mathbf{E r} / \mathbf{E d}$ & $\mathbf{E r} / \mathbf{E d}$ & $\mathbf{E r} / \mathbf{E d}$ & $\mathbf{E r} / \mathbf{E d}$ & $\mathbf{E r} / \mathbf{E d}$ & $\mathbf{E r} / \mathbf{E d}$ & Er + Ed \\
\hline \multirow[t]{5}{*}{$\bar{A}$} & 0 & $-/-$ & $-/-$ & -/- & -/- & $-/-$ & $-/-$ & \\
\hline & 24 & $2 / 0$ & $2 / 0$ & $2 / 0$ & $1 / 0$ & $2 / 0$ & $2 / 0$ & 11 \\
\hline & 48 & $1 / 0$ & $2 / 0$ & $1 / 0$ & $1 / 0$ & $1 / 0$ & $1 / 0$ & \\
\hline & 72 & $1 / 0$ & $2 / 0$ & $1 / 0$ & $1 / 0$ & $1 / 0$ & $1 / 0$ & 7 \\
\hline & & & & & & & & ${ }^{\mathrm{b}} I I P=1.5$ \\
\hline \multirow[t]{5}{*}{$\overline{\mathbf{B}}$} & 0 & $-/-$ & $-/-$ & $-/-$ & $-/-$ & $-/-$ & $-/-$ & \\
\hline & 24 & $2 / 0$ & $2 / 0$ & $3 / 1$ & $2 / 0$ & $3 / 1$ & $2 / 0$ & 16 \\
\hline & 48 & $2 / 0$ & $2 / 0$ & $3 / 0$ & $2 / 0$ & $3 / 0$ & $2 / 0$ & \\
\hline & 72 & $2 / 0$ & $1 / 0$ & $2 / 0$ & $2 / 0$ & $3 / 0$ & $1 / 0$ & 11 \\
\hline & & & & & & & & ${ }^{\mathrm{b}} \mathbf{I I P}=\mathbf{2 . 3}$ \\
\hline \multirow[t]{4}{*}{$\overline{\mathrm{C}}$} & 0 & $-/-$ & $-/-$ & $-/-$ & $-/-$ & -/- & $-/-$ & \\
\hline & 24 & $3 / 1$ & $3 / 1$ & $3 / 1$ & $3 / 1$ & $3 / 0$ & $3 / 1$ & 23 \\
\hline & 48 & $2 / 0$ & $2 / 0$ & $2 / 0$ & $2 / 0$ & $3 / 0$ & $2 / 0$ & \\
\hline & 72 & $2 / 0$ & $2 / 0$ & $2 / 0$ & $2 / 0$ & $3 / 0$ & $2 / 0$ & 13 \\
\hline
\end{tabular}

${ }^{\mathrm{a}}$ IIP was calculated as the aritmetic mean from the $24 \mathrm{~h}$ and $72 \mathrm{~h}$ readings of $\mathrm{Er}$ and Ed. ${ }^{\mathrm{b}}$ Meanings of values of IIP were, $1.5=$ slightly irritating, 2.3 to $3.0=$ moderately irritating.

TABLE V - Edema (Ed) and Erythema (Er) measured from tests conducted after application of a chemical agent used in automobile industry ${ }^{\text {a }}$. Twelve guinea-pigs were used ( $1^{\text {st }}$ to $6^{\text {th }}$ guinea-pigs with normal skin and $7^{\text {th }}$ to $12^{\text {th }}$ guinea-pig with abrased skin) $)^{\text {a, b }}$

\begin{tabular}{|c|c|c|c|c|c|c|c|c|c|c|c|c|}
\hline \multirow{3}{*}{$\begin{array}{l}\text { Time of } \\
\text { Application } \\
\text { (h) }\end{array}$} & \multicolumn{12}{|c|}{ Guinea-pig } \\
\hline & 1 & 2 & 3 & 4 & 5 & 6 & 7 & 8 & 9 & 10 & 11 & 12 \\
\hline & ${ }^{b} \mathbf{E} \mathbf{r} / \mathbf{E d}$ & $\mathbf{E r} / \mathbf{E d}$ & $\mathbf{E r} / \mathbf{E d}$ & Er/Ed & $\mathbf{E r} / \mathbf{E d}$ & Er/Ed & Er/Ed & $\mathbf{E r} / \mathbf{E d}$ & $\mathbf{E r} / \mathbf{E d}$ & $\mathbf{E r} / \mathbf{E d}$ & $\mathbf{E r} / \mathbf{E d}$ & Er/Ed \\
\hline 0 & $-/-$ & $-/-$ & $-/-$ & $-/-$ & $-/-$ & $-/-$ & $-/-$ & $-/-$ & $-/-$ & $-/-$ & $-/-$ & $-/-$ \\
\hline 24 & $3 / 1$ & $3 / 1$ & $3 / 1$ & $3 / 1$ & $3 / 1$ & $3 / 1$ & $3 / 1$ & $3 / 1$ & $2 / 0$ & $2 / 0$ & $3 / 1$ & $3 / 1$ \\
\hline 48 & $3 / 0$ & $3 / 0$ & $3 / 0$ & $3 / 0$ & $2 / 0$ & $2 / 0$ & $3 / 0$ & $2 / 0$ & $2 / 0$ & $2 / 0$ & $2 / 0$ & $3 / 0$ \\
\hline 72 & $2 / 0$ & $3 / 0$ & $2 / 0$ & $3 / 0$ & $2 / 0$ & $1 / 0$ & $3 / 0$ & $2 / 0$ & $1 / 0$ & $1 / 0$ & $1 / 0$ & $2 / 0$ \\
\hline
\end{tabular}

${ }^{a}$ Performed on May 1989. ${ }^{b}$ The primary irritation index (IIP) of the sample was calculated as in the previous table, as the aritmetic mean of the $24 \mathrm{~h}$ and $72 \mathrm{~h}$ readings of Er and Ed, attaining a value of 2.8 (moderately irritating).

TABLE VI - Edema (Ed) and Erythema (Er) measured from tests conducted after application of a liquid soapa. Twelve guinea-pigs were used $\left(1^{\text {st }}\right.$ to $6^{\text {th }}$ guinea-pigs with normal skin and $7^{\text {th }}$ to $12^{\text {th }}$ guinea-pigs with abraded skin) ${ }^{\text {b,c }}$

\begin{tabular}{|c|c|c|c|c|c|c|c|c|c|c|c|c|}
\hline \multirow{3}{*}{$\begin{array}{l}\text { Time of } \\
\text { Application } \\
\text { (h) }\end{array}$} & \multicolumn{12}{|c|}{ Guinea-pig } \\
\hline & 1 & 2 & 3 & 4 & 5 & 6 & 7 & 8 & 9 & 10 & 11 & 12 \\
\hline & ${ }^{c} \mathbf{E r} / \mathbf{E d}$ & $\mathbf{E r} / \mathbf{E d}$ & $\mathbf{E r} / \mathbf{E d}$ & $\mathbf{E r} / \mathbf{E d}$ & $\mathbf{E r} / \mathbf{E d}$ & $\mathbf{E r} / \mathbf{E d}$ & $\mathbf{E r} / \mathbf{E d}$ & Er/Ed & $\mathbf{E r} / \mathbf{E d}$ & $\mathbf{E r} / \mathbf{E d}$ & $\mathbf{E r} / \mathbf{E d}$ & Er/Ed \\
\hline 0 & $-/-$ & $-/-$ & $-/-$ & $-/-$ & $-/-$ & $-/-$ & $-/-$ & $-/-$ & $-/-$ & $-/-$ & $-/-$ & $-/-$ \\
\hline 24 & $0 / 0$ & $0 / 0$ & $0 / 0$ & $0 / 0$ & $0 / 0$ & $0 / 0$ & $0 / 0$ & $0 / 0$ & $0 / 0$ & $0 / 0$ & $0 / 0$ & $0 / 0$ \\
\hline 48 & $0 / 0$ & $0 / 0$ & $0 / 0$ & $0 / 0$ & $0 / 0$ & $0 / 0$ & $0 / 0$ & $0 / 0$ & $0 / 0$ & $0 / 0$ & $0 / 0$ & $0 / 0$ \\
\hline 72 & $0 / 0$ & $0 / 0$ & $0 / 0$ & $0 / 0$ & $0 / 0$ & $0 / 0$ & $0 / 0$ & $0 / 0$ & $0 / 0$ & $0 / 0$ & $0 / 0$ & $0 / 0$ \\
\hline
\end{tabular}

${ }^{\mathrm{a}}$ Conducted in November $1993 .{ }^{\mathrm{b}}$ The sample was gently rubbed on the back skin for $1 \mathrm{~min}$ and $5 \mathrm{~min}$ after followed by 10 washings of $50 \mathrm{~mL}$ each of sterile slightly heated distilled water. ${ }^{\mathrm{c}}$ The primary irritation index (IIP) of the sample was calculated as in the previous tables, as the aritmetic mean of the $24 \mathrm{~h}$ and $72 \mathrm{~h}$ readings of Er and Ed. In this case since edema and erythema were absent, the value of IIP was 0.0 (not irritating). 
TABLE VII - Edema (Ed) and Erythema (Er) measured from tests of sensitization conducted according to the OECD method, after application of two samples (A and B) of a shellac paint. Ten guinea-pigs were used as tests for each shellac paint, as well as 10 guinea-pigs as the corresponding shellac-free controls ${ }^{\text {a }}$

\begin{tabular}{|c|c|c|c|c|c|c|c|c|c|}
\hline \multirow[t]{2}{*}{$\begin{array}{l}\text { Number of } \\
\text { the guinea-pig } \\
\text { tested }\end{array}$} & \multicolumn{2}{|c|}{$\begin{array}{c}\text { Shellac A } \\
\text { Er/Ed } \\
\text { Time (h) }\end{array}$} & \multicolumn{2}{|c|}{$\begin{array}{l}\text { Shellac B } \\
\text { Er/Ed } \\
\text { Time (h) }\end{array}$} & \multirow{2}{*}{$\begin{array}{l}\text { Number of } \\
\text { the control } \\
\text { Guinea-pig }\end{array}$} & \multicolumn{2}{|c|}{$\begin{array}{c}\text { Shellac A } \\
\text { Er/Ed } \\
\text { Time (h) }\end{array}$} & \multicolumn{2}{|c|}{$\begin{array}{l}\text { Shellac B } \\
\text { Er/Ed } \\
\text { Time (h) }\end{array}$} \\
\hline & 24 & 48 & 24 & 48 & & 24 & 48 & 24 & 48 \\
\hline 01 & $0 / 0$ & $0 / 0$ & $0 / 0$ & $0 / 0$ & 11 & $1 / 0$ & $1 / 0$ & $1 / 0$ & $0 / 0$ \\
\hline 02 & $1 / 0$ & $1 / 0$ & $1 / 0$ & $0 / 0$ & 12 & $1 / 0$ & $0 / 0$ & $0 / 0$ & $0 / 0$ \\
\hline 03 & $0 / 0$ & $0 / 0$ & $0 / 0$ & $0 / 0$ & 13 & $0 / 0$ & $0 / 0$ & $0 / 0$ & $0 / 0$ \\
\hline 04 & $1 / 0$ & $0 / 0$ & $1 / 0$ & $1 / 0$ & 14 & $1 / 0$ & $1 / 0$ & $1 / 0$ & $0 / 0$ \\
\hline 05 & $1 / 0$ & $0 / 0$ & $0 / 0$ & $0 / 0$ & 15 & $0 / 0$ & $0 / 0$ & $0 / 0$ & $0 / 0$ \\
\hline 06 & $1 / 0$ & $1 / 0$ & $0 / 0$ & $0 / 0$ & 16 & $0 / 0$ & $0 / 0$ & $0 / 0$ & $0 / 0$ \\
\hline 07 & $1 / 0$ & $0 / 0$ & $1 / 0$ & $0 / 0$ & 17 & $1 / 0$ & $0 / 0$ & $2 / 0$ & $1 / 0$ \\
\hline 08 & $0 / 0$ & $0 / 0$ & $2 / 0$ & $1 / 0$ & 18 & $1 / 0$ & $1 / 0$ & $1 / 0$ & $1 / 0$ \\
\hline 09 & $0 / 0$ & $0 / 0$ & $0 / 0$ & $0 / 0$ & 19 & $1 / 0$ & $0 / 0$ & $1 / 0$ & $0 / 0$ \\
\hline 10 & $2 / 0$ & $1 / 0$ & $1 / 0$ & $0 / 0$ & 20 & $0 / 0$ & $0 / 0$ & $1 / 0$ & $0 / 0$ \\
\hline Mean $^{\mathrm{b}}$ & \multicolumn{2}{|c|}{$0.50^{\mathrm{c}}$} & \multicolumn{2}{|c|}{$0.40^{\mathrm{c}}$} & & \multicolumn{2}{|c|}{$0.45^{\mathrm{c}}$} & \multicolumn{2}{|c|}{$0.45^{\mathrm{c}}$} \\
\hline
\end{tabular}

${ }^{a}$ Induction performed on $05 / 02 / 92$ and challenge on $12 / 02 / 92 .{ }^{b}$ Means were calculated from the summations of the 20 values of $\mathrm{Er} / \mathrm{Ed}$ for the 2 time periods ( $24 \mathrm{~h}$ and $48 \mathrm{~h}$ ) for each shellac paint and respective controls. ${ }^{\mathrm{c}}$ The difference between the means for tested and control samples was zero or close to zero for shellacs A or B, indicating that both agents were non-sensitizing.

guinea-pigs tested and controls for shellac paint was practically zero $(0.50-0.45=0.05)$. A similar negligible difference was found for shellac $\mathrm{B}(0.40-0.45=-0.05)$. In conclusion, the samples tested for shellacs A and B, through the OECD method, presented indexes of sensitization corresponding to the classification of non-sensitizing, a finding that differed to the results by the OET method, as shown below.

\section{Skin sensitization test by the OET method (Open Epicutaneous Test)}

\section{Results}

The results of the study of contact sensitization performed in March 1992 with the same two samples of shellacs A and B, now by the OET method, are shown in Table VIII. All the guinea-pigs receiving undiluted solutions, as well as $30 \%$ and $10 \%$ dilutions presented a positive reaction macroscopically (i.e. edema end erythema larger than controls) when challenged on days 21 and 35 . The dilution of $3 \%$ did not cause irritation or sensitization and did not leave a red stain. This was previously confirmed through the irritation index of samples, described above. Under microscopic examination, the areas with positive reaction revealed accumulation of macrophages, lymphocytes and plasmocytes, indicating an inflammatory immunomediated reaction. The guineapigs of the test groups for dilutions greater than or equal to $10 \%$ developed contact sensitization by the method of

TABLE VIII - Tests of sensitization conducted according to the OET method, after application of two samples (A and B) of a shellac paint, that were undiluted (pure), or 10\% and 30\% diluted. Six guinea-pigs were used as tests for each shellac, as well as 6 guineapigs as the corresponding shellac-free controls ${ }^{a}$

\begin{tabular}{|c|c|c|c|c|c|c|c|c|c|c|c|}
\hline \multirow{2}{*}{$\begin{array}{l}\text { Number of } \\
\text { Guinea-pig }\end{array}$} & \multirow{2}{*}{$\begin{array}{l}\text { Time } \\
\text { (h) }\end{array}$} & \multicolumn{5}{|c|}{$\begin{array}{l}\text { Results of challenge on the } 21^{\text {st }} \text { day } \\
\text { shellac A and } \mathrm{B}^{\mathrm{c}}\end{array}$} & \multicolumn{5}{|c|}{$\begin{array}{l}\text { Results of challenge on the } 35^{\text {th }} \text { day }{ }^{\mathrm{a}} \\
\text { shellac A and } \mathrm{B}^{\mathrm{c}}\end{array}$} \\
\hline & & $\begin{array}{l}\text { Pure } \\
\text { Group }\end{array}$ & $\begin{array}{l}30 \% \\
\text { Group }\end{array}$ & $\begin{array}{l}10 \% \\
\text { Group }\end{array}$ & $\begin{array}{c}\% \\
\text { Group }\end{array}$ & $\begin{array}{l}\text { Control } \\
\text { Group }\end{array}$ & $\begin{array}{l}\text { Pure } \\
\text { Group }\end{array}$ & $\begin{array}{l}30 \% \\
\text { Group }\end{array}$ & $\begin{array}{l}10 \% \\
\text { Group }\end{array}$ & $\begin{array}{c}3 \% \\
\text { Group }\end{array}$ & $\begin{array}{l}\text { Control } \\
\text { Group }\end{array}$ \\
\hline \multirow[t]{3}{*}{1 to $6^{b}$} & 24 & + & + & + & - & - & + & + & + & - & - \\
\hline & 48 & + & + & + & - & - & + & + & + & - & - \\
\hline & 72 & + & + & + & - & - & + & + & + & - & - \\
\hline
\end{tabular}

$+=$ positive reaction , $-=$ negative reaction. ${ }^{\text {a }}$ Challenge was made on the $21^{\text {st }}$ day, on $05 / 03 / 92$, and on the $35^{\text {th }}$ day, on 19/03/92. ${ }^{b}$ The results for guinea-pigs 1 to 6 were similar. ${ }^{\mathrm{c}}$ The sensitization for groups of dilutions $10 \%, 30 \%$ and pure was positive, corresponding to the classification of the shellacs as sensitizing 
OET (minimal concentration necessary for the induction of contact hypersensitivity). It was concluded that the samples of shellacs A and B presented a sensitization index corresponding to the classification of sensitizing, according to the OET method.

In conclusion, the OET method was found to be more sensitive than OECD, presenting a higher correlation between results in guinea-pigs and men, as can be inferred on the basis of data reporting that both types of shellac paint produced contact allergy in children from the south of Brazil (personal information).

\section{OTHER ASSAYS PERFORMED}

The results corresponding to 400 of the 602 tests for evaluation of short term toxicity have been presented. The remaining 202 tests are summarized in Table IX, corresponding to the following tests and results (in parenthesis): 90 for ocular irritation ( $64.4 \%$ non-irritating and $35.6 \%$ irritating, before discontinuation in 1995), 31 for systemic toxicity by injection (all the samples approved as non toxic), 26 for oral acute toxicity (24 approved and 2 not approved), 15 for toxicity by intracutaneous application (13 approved and 2 not approved), 15 for toxicity of serum and vaccines for human use (all approved), 14 for toxicity by intramuscular implantation ( 7 approved and 7 not approved), 7 for pyrogen (all approved as non pyrogenic), 2 for acute dermal toxicity (all approved as non toxic) and 2 for irritation of mucosa (approved as nonirritating).

\section{PERSPECTIVES: NEW POSSIBILITIES FOR TESTS OF CUTANEOUS IRRITATION AND SENSITIZATION}

Several alternative tests have been presented or suggested, most of them close to the end of last century, with the main objective to comply with the principles of the 3 Rs ( "refinement, reduction and replacement") of Russel and Burch (1959) aiming to obtain better results with less animals and higher sensitivity, or by using methods in vitro. Some of these tests have not yet been used in Cedeme and will be briefly mentioned or described below.

\section{(1) Sequential two-step irritation test with a minimum number of animals.}

The Guidelines for the testing of chemicals N. 404 of OECD, revised in 2002 (OECD, 2002b) and, along similar lines the Guideline OPPTS 870.2500 of EPA(USA) recommends the strategy for the initial use of only one animal in tests "in vivo", with a sequential application in 3 different areas after $3 \mathrm{~min}, 1 \mathrm{~h}$ and $4 \mathrm{~h}$. If an irritation is seen in any of the three applications the test should not be continued. Else, two more animals should be used with only one application site in each.

\section{(2) Human skin model test and transcutaneous electrical resistance test for evaluation of skin corrosion in vitro.}

These two methods were proposed as an improvement to evaluate skin corrosion, and adopted by OECD since February 2004, after studies and recommendations

TABLE IX - Summary of results for 202 tests not outlined above, from the total of 602 tests conducted at Cedeme from January 1986 to December 2000 (CR = cosmetics and related agents; $\mathrm{ME}=$ medicines; $\mathrm{PRP}=$ plastics, rubber and other polymers; ICH = industrial chemicals ; VA = vaccines; $\mathrm{A}=$ agrotoxics)

\begin{tabular}{|c|c|c|c|c|c|c|c|c|}
\hline \multirow{2}{*}{ Test } & \multirow{2}{*}{ Result } & \multicolumn{7}{|c|}{ Type of agent } \\
\hline & & CR & ME & PRP & $\mathrm{ICH}$ & VA & $\mathrm{A}$ & Total \\
\hline Eye Irritation ${ }^{a}$ & Non irritating & $42(20)^{b}$ & - & 05 & 09 & - & $02(12)^{b}$ & 90 \\
\hline Oral DL50 & Non toxic ${ }^{c}$ & - & $09(01)^{d}$ & 07 & $08(01)^{d}$ & - & - & 26 \\
\hline Mucosa Irritation & Non irritating & 02 & - & - & - & - & - & 02 \\
\hline Systemic injection & Non toxic & - & 01 & 30 & - & - & - & 31 \\
\hline Pyrogen & Non pyrogenic & - & 01 & 06 & - & - & - & 07 \\
\hline Intracutaneous & Non toxic & - & - & $13(02)^{\mathrm{e}}$ & - & - & - & 15 \\
\hline Implantation & Non toxic & - & - & $07(07)^{\mathrm{e}}$ & - & - & - & 14 \\
\hline Dermal DL 50 & Non toxic ${ }^{f}$ & - & - & - & 02 & - & - & 02 \\
\hline Vaccines & Non toxic & - & - & - & - & 15 & - & 15 \\
\hline Total & & 64 & 12 & 77 & 20 & 15 & 14 & 202 \\
\hline
\end{tabular}

${ }^{\mathrm{a}}$ discontinued in $1995 ;{ }^{\mathrm{b}}$ In parenthesis = irritating; ${ }^{\mathrm{c}}$ When DL50 is higher than $5000 \mathrm{mg} / \mathrm{kg}$; ${ }^{\mathrm{d}}$ In parenthesis $=$ toxic, since the DL50 was lower than $5000 \mathrm{mg} / \mathrm{kg}$; ${ }^{\mathrm{e}}$ In parenthesis = toxic; ${ }^{\mathrm{f}}$ When DL50 is higher than $2000 \mathrm{mg} / \mathrm{kg}$ 
made by Barratt et al. (1998), Fentem et al. (1998), Balls et al. (1995), Liebsch et al. (2000), ICCVAM (1997; 2002) and $\operatorname{OECD}(1996 ; 2002 \mathrm{a})$.

\section{(3) Maximization test of Magnusson and Kligman (1969)} and of Buehler (1965), to evaluate skin sensitivity.

Both tests are recommended by the Guidelines of OECD when adopted in 1981 (OECD, 1981d) and revised in July 1992 (OECD, 1992). The main difference between the two tests is that Kligman (1969) uses the Freund 's Complete Adjuvant, in contrast to Buehler (1965).

(4) Mouse ear swelling test (Gad et al., 1986), and local lymph node assay (Kimber et al., 1989; 1990; 1991; Baskett et al., 1991)

Both assays can be used as a first step to detect skin sensitization. If the result is positive for the mouse, the test in guinea pigs is unnecessary.

The local lymph node assay (LLNA), was suggested in USA by ICCVAM (1997) as an alternative to replace the test in guinea-pigs (Basketter et al., 2002). It was adopted by OECD on April 24, 2002 (OECD, 2002c). This in vivo test uses a smaller number of animals and does not require the use of Freund's Complete Adjuvant. However, there are some limitations, because of the findings of some false negative or false positive results (NIEHS, 1999).

\section{CONCLUSIONS}

A large number of assays of toxicity and innocuity were carried out entirely in animal laboratory facilities, pursuant to the guidelines of the main international regulatory agencies, including the OECD and the International Conference on Harmonization (ICH), that hold high credibility in the USA, Europe and Japan. These assays used the corresponding good laboratory practices and followed, whenever possible, the 3 Rs principle of Russel and Burch (1959) outlined above.

Notwithstanding a small number of tests that were not performed, although mentioned as candidates for future assays, eleven different types of tests were conducted using agent such as cosmetics, chemicals, medicines, vaccines, polymers and agrotoxics. Some details of parts of the tests were described in this paper, including points that were slightly adapted, leading to a conclusion on the feasibility of performing these in the Brazilian milieu.

Besides the scientific and technical interests, these assays are procedures sine qua non, and obligatory in order to assure the absence of toxicity for compounds tested for chemical and pharmaceutical industries as well as for licensing of medicines and other agents.
The present study is also an example of the contribution of the Laboratory of Animal Science to our technical and scientific development. It was initiated on the basis of a pioneering concern to assure that the animal facilities should not be merely a producer of animals, but should contribute directly to the objectives of the university as a school in which professionals and students are also supposed to participate in research, teaching and technical activities.

\section{REFERENCES}

BALLS, M.; BLAAUBOER, B. J.; FENTEM, J. H.; BRUNER, L.; COMBES, R. D.; EKWALL, B.; FIELDER, R. J.; GUILlOUZO, A.; LEWIS, R. W.; LOVELL, D. P.; REINHARDT, C. A.; REPETTO, G.; SLADOWSKI, D.; SPIELMANN, H.; ZUCCO, F. Practical aspects of the validation of toxicity test procedures. The report and recommendations of ECVAM workshops. ATLA, v.23, p.129-147, 1995.

BARRATT, M. D.; BRANTOM, P. G.; FENTEM, J. H.; GERNER, I.; WALKER, A. P.; WORTH, A. P. The ECVAM international validation study on in vitro tests for skin corrosivity. 1. Selection and distribution of the test chemicals. Toxicol. in vitro, v.12, p.471-482, 1998.

BASKETTER, D. A.; SCHOLES, E. W.; KIMBER, I.; BOTHAM, P. A.; HILTON, J.; MILLER, K.; ROBBINS, M. C.; HARRISON, P. T. C.; WAITE, S. J. Interlaboratory evaluation of the local lymph node assay with 25 chemicals and comparison with guinea pig test data. Toxicol. Meth., v.1, p.30-43, 1991.

BASKETTER, D. A.; EVANS, P.; FIELDER, R. J.; GERBERICK, G. F.; DEARMAN, R. J.; KIMBER, I. Local lymph node assay - validation, conduct and use in practice. Food Chem. Toxicol., v.40, p.593-598, 2002.

BROWN, V. K. H. A comparison of predictive irritation tests with surfactants on human and animal skin. J. Soc. Cosmet. Chem., v.22, p.411-420, 1971.

BROWN, V. K. H. Acute toxicity testing - a critique. In: GORROD, J.W. (Ed.) Testing for toxicity. London: Taylor \& Francis, 1981. p.21-27.

BUEHLER, E. V. Delayed contact hypersensitivity in the guinea pig. Arch. Dermatol., v.91, p.171-177, 1965. 
DAVIES, R. E.; HARPER, K. H.; HYNOCH, S. R. Interspecies variation in dermal reactivity. J. Soc. Cosmet. Chem., v.23, p.371, 1972.

DRAIZE, J. H.; WOODARD, G.; CALVERY, H. O. Methods for the study of irritations and toxicity of substances applied topically to skin and mucous membranes. J. Pharmacol. Exp. Ther., v.83, p.377-390, 1944.

DRAIZE, J. H. Dermal toxicity. In: FOOD \& DRUG OFFICIALS OF USA. Appraisal of the safety of chemicals in foods, drugs and cosmetics. Austin: Association of Food and Drug Officials of the United States, 1959. p.26-51, p.46-59.

FENTEM, J. H.; ARCHER, G. E. B.; BALLS, M.; BOTHAM, P. A.; CURREN, R. D.; EARL, L. K.; EDSAIL, D. J.; HOLZHUTTER, H. G.; LIEBSCH, M. The ECVAM international validation study on "in vitro" tests for skin corrosivity. 2 . Results and evaluation by the management team. Toxicol. in vitro, v.12, p.483-524, 1998.

GAD, S. C.; DUNN, B. J; DOBBS, D. W; REILLY, C.; WALSH, R. D. Development and validation of an alternative dermal sensitization test: the mouse ear swelling test. Toxicol. Appl. Pharmacol., v.84, p.93-114, 1986.

HANGAN, J. M. Acute toxicity. In: FOOD \& DRUG OFFICIALS OF USA Appraisal of the safety of chemicals in food, drugs and cosmetics. Austin: Association of Food and Drug Officials of the United States 1959. p.17-25.

INTERAGENCY COORDINATING COMMITTEE ON THE VALIDATION OF ALTERNATIVE METHODS. ICCVAM. Validation and regulatory acceptance of toxicological test methods. Part II: Validation of test methods. In: NIH Publication no: 97-3981. North Carolina: Research Triangle Park, National Toxicology Program, 1997. p.1-18.

INTERAGENCY COORDINATING COMMITTEE ON THE VALIDATION OF ALTERNATIVE METHODS ICCVAM. Evaluation of EpiDermTM, EPISKINTM (EPI-200), and the Rat Skin Transcutaneous Electrical Resistance (TER) assay: In Vitro test methods for assessing dermal corrosivity potential of chemicals. In: NIH Publication No. 02-4502. North Carolina: Research Triangle Park, National Toxicology Program, 2002. p.1-93.
KLECAK, G.; GELEICK, H.; FREY, J. R. Screening of fragrance materials for allergenicity in the guinea pig. I. Comparison of four testing methods. J. Soc. Cosmet. Chem., v.28, p.53-64, 1977.

KIMBER, I.; HILTON, J.; WEISNBERGER, C. The murine local lymph node assay for identification of contact allergens: a preliminary evaluation of in situ measurement of lymphocyte proliferation. Con. Dermat., v.21, p.215220, 1989.

KIMBER, I.; HILTON, J.; BOTHAM, P. A. Identification of contact allergens using the murine local lymph node assay: comparisons with the Buchler Occludes Pach Test in guinea pigs. J. Appl. Toxicol., v.10, p.173-180, 1990.

KIMBER, I.; HILTON, J.; BOTHAM, P. A.; BASKETTER, D. A.; SCHOLES, E. W.; MILLER, K.; ROBBINS, M. C.; HARRISON, P. T. C.; GRAY, T. J. B.; WAITE, S. J. The murine local lymph node assay: results of an interlaboratory trial. Toxicol. Lett., v.55, p.203-213, 1991.

LAUTIER, F.; RAZAFITSALAMA, D.; LAVILLAURES, J. Le cobaye, animal de choix pour teste d'irritabilite et d'agressivite cutanee en l'animal de laboratorie a service de l'homme. In: CONGRES INTERNATIONAL ORGANIZE A I'ECOLE VETERINAIRE DE LYON, 1, Lyon, 1978. Proceedings. Lyon: Fondation Marcel Mérieux, 1978. n.p. (Collection Fondation Mérieux).

LIEBSCH, M.; TRAUE, D.; BARRABAS, C.; SPIELMANN, H.; UPHILL, P.; WILKINS, S.; MCPHERSON, J. P.; WIEMANN, C.; KAUFMANN, T.; REMMELE, M.; HOLZHÜTTER, H-G. The ECVAM prevalidation study on the use of EpiDerm for skin corrosivity testing. ATLA, v.28, p.371-401, 2000.

LOOMIS, T. A. Acute and prolonged toxicity tests. JAOAC, v.58, p.645-649, 1975.

MAGNUSSON, B.; KLIGMAN, A. M. The identification of contact allergens by animal assay. The guinea pig maximization test. J. Invest. Dematol., v.52, p.268, 1969.

MAGNUSSON, B. Identification of contact sensitizers by animal assay. Cont. Derm., v.6, p.46, 1980.

MARZULLI, F. N.; MAIBACH, H. I. Rabbit as a model for evaluating skin irritants: a comparison of results obtained on animals and man using repeated skin exposures. Food Cosmet. Toxicol., v.13, p.533-540, 1975. 
MIDDLETON, M. C. New approaches to problems of dermatotoxicity. In: GORROD, J. W. (Ed.) Testing for toxicity. London: Taylor \& Francis, 1981. p.275-295.

MORTON, D. M. Requirements for the toxicological testing of drugs in the USA, Canada and Japan. In: GORROD, J. W. (Ed.). Testing for toxicity. London: Taylor \& Francis, 1981. p.11-19.

MORTON, D. M. Importance of species selection in drug toxicity testing. Toxicol. Lett., v.102, p.545-550, 1998.

NATIONAL INSTITUTE OF ENVIRONMENTAL HEALTH SCIENCES. NIEHS The murine local lymph node assay. In: NIH Publication No: 99-4494. North Carolina: Research Triangle Park: National Toxicology Program, 1999. p.1-44.

ORGANIZATION FOR ECONOMIC CO-OPERATION AND DEVELOPMENT. OEDC. Acute dermal irritation/ corrosion. n.404. In: OECD Guidelines for testing of chemicals. Section 4, Health effects. Paris: OECD, 1981a. $6 \mathrm{p}$.

ORGANIZATION FOR ECONOMIC CO-OPERATION AND DEVELOPMENT. OEDC. Skin sensitisation. n.406. In: OECD Guidelines for testing of chemicals. Section 4, Health effects. Paris: OECD, 1981b. 6 p.

ORGANIZATION FOR ECONOMIC CO-OPERATION AND DEVELOPMENT. OEDC. Skin sensitisation. n.406. In: OECD Guidelines for testing of chemicals. Section 4, Health effects. Paris: OECD, 1992. 9 p.

ORGANIZATION FOR ECONOMIC CO-OPERATION AND DEVELOPMENT. OEDC. Test guidelines programme. In: WORKSHOP ON HARMONIZATION OF VALIDATION AND ACCEPTANCE CRITERIA FOR ALTERNATIVE TOXICOLOGICAL TEST METHODS, 1, Solna. Proceedings. Paris: OECD, 1996. 62 p.

ORGANIZATION FOR ECONOMIC CO-OPERATION AND DEVELOPMENT. OEDC. Extended Expert Consultation Meeting on the in vitro skin corrosion Test Guideline Proposal. In: OECD ENV/EHS, 1, Berlin, 2001. Proceedings. Paris: OECD, 2002a. n.p.
ORGANIZATION FOR ECONOMIC CO-OPERATION AND DEVELOPMENT. OEDC. Acute dermal irritation/ corrosion. n.404. In: OECD Guidelines for testing of chemicals. Section 4, Health effects. Paris: OECD, $2002 \mathrm{~b}$. $13 \mathrm{p}$.

ORGANIZATION FOR ECONOMIC CO-OPERATION AND DEVELOPMENT. OEDC. Skin sensitization: Local lymph node assay. n.429. In: OECD Guidelines for testing of chemicals. Section 4, Health effects. Paris: OECD, 2002c. $7 \mathrm{p}$.

PARISH, W. E. Immunological tests to predict toxicological hazards to man. In: GORROD, J. W. (Ed.). Testing for toxicity. London: Taylor \& Francis, 1981. p.297-315.

SILVA, P. Farmacologia. 3.ed. apud RANG, H. P.; DALE, M. M.; RITTER, J. M.; MOORE, P. K. Rio de Janeiro: Guanabara Koogan, 1997. p.177-179.

RUSSELL, M.; BURCH, R. The principles of humane experimental techniques, 1959 apud RUSSELL W. M. The development of the three Rs concept. Altern. Lab. Anim., v.23, p.298-304, 1995.

SOMERS, G. F. Testing drugs for dermal toxicity. J. Soc. Cosmetic. Chem., v.15, p.385-394, 1964.

SWANSTON, D. W. Assessment of the validity of animal techniques in eye-irritation testing. Food Chem. Toxicol., v.23, p.169-173, 1985.

USA. Code of Federal Regulations Method of testing primary irritant substances. Method of testing primary irritant substances. In: Code of Federal Regulations - Title 16: Commercial Practices, Chapter II, Section 1500.41. Washington: U.S. Government Printing Office, 1976. n.p.

Received for publication on $14^{\text {th }}$ April 2009 Accepted for publication on $19^{\text {th }}$ August 2009 